\title{
Interrogating Students' Engagement in Academic Work in a Selected University in Zimbabwe
}

\author{
Madzanire Daniel \\ Great Zimbabwe University, Zimbabwe \\ Maphosa Cosmas \\ University of Fort Hare, South Africa \\ Email: cmaphosa@ufh.ac.za \\ Zikhali Joyce
}

University of Johannesburg, South Africa

Chauraya Efiritha

Midlands State University, Zimbabwe

Doi:10.5901/mjss.2014.v5n16p247

\section{Abstract}

The extent to which students' attain learning outcomes and the overall quality of a qualification is dependent on the extent to which the student is engaged in academic work inside and outside the lecture room. The study sought to establish the extent to which students were engaged in academic work in a Zimbabwean university. The study followed a mixed methods approach, in which a case study design was utilized. Data were solicited from students in five selected faculties in the one selected university. A convenient sample of 110 students participated in the study. A semi-structured questionnaire was used to collect both quantitative and qualitative data. Quantitative data were analysed with the aid of the SPSS statistical software package version 21. Qualitative data were analysed using content analysis method and presented through verbatim quotations of the respondents. The study found that tasks related to passing examinations were allocated more time and those deemed to not to be directly important in passing examinations were not considered important. It is concluded that examination-focused learning played a crucial role on determining time spent on tasks. Recommendations were made.

Keywords: Students. Academic work. Engagement. Learning outcomes. Quality education

\section{Introduction and Background}

Research in higher education teaching and learning has witnessed student engagement as a buzz word (Krause, 2005; Ndudzo, 2013). Other scholars argue that the quality of one's qualification obtained in a university is dependent on the extent to which the individual was academically engaged in the studies. Christenson, Stout and Pohl (2012) argue that students should actively participate in academic activities in order to achieve learning outcomes.

Lysne, Miller and Eitel (2013) explain that student engagement is a term that refers to time, energy and resources students spend on activities designed to enhance learning. Hu and McComick (2012) explain that the concept of student engagement originates from Astin's theory of involvement and the quality of effort exerted by students. Astin's 1984 theory identifies students' involvement in academia, campus life, organisational and faculty activities as of grave importance to their educational achievement (Price \& Baker, 2012). The theory focuses on behaviours in which students engage in traditional forms of academic, social and academic experiences. It focuses largely on the physical behaviours in which students participate in campus life and interact with faculty and peers as they engage in activities like competitions, performances and studying (Price \& Baker, 2012). Astin argues that the quality and quantity of students' involvement is directly related to the developmental growth of their experiences (Price \& Baker, 2012).

Student engagement is a critical endeavour which every educator must strive to achieve. Lysne et al (2013) are of the view that student engagement is crucial in capturing student interest to ensure that learning occurs. Hu \& McCormick 
(2012) suggest that the quality of education that students obtain is of prime concern to national discourse on higher education reform. Research by Brusi, Portnoy \& Toro (2013) on student engagement in communication and information technology in the United States of America (USA) support the importance of student engagement and suggests that it has an impact on their academic achievement. On a similar note, Hu and McCormick (2012) cite literature (Astin, 1993a; Hu Kuh, 2003) which points to a positive correlation between student engagement and grades, satisfaction, perceived gains in learning, personal development and persistence. Similarly, scholars (Landis \& Reschly, 2013; Carter, Reschly, Lovelace, Appleton \& Thompson, 2012; Carter \& Fountaine, 2012) associate student engagement with a number of student competencies which include social-emotional being as well as long time outcomes like educational attainment and work, critical thinking skills, leadership, identity development, and success. The above views concur with Brusi et al. (2013) whose study in America suggests a lack of class participation and discussion of problems as causes of failure to student learning. As such, student engagement has become a benchmark for institutional quality and measure of student learning.

Landis and Reschly (2013) explain that student engagement is affected by variables which are influenced by social contexts such as the home, school and peers and is to a large extent associated with important outcomes of interest, including achievement and school completion. Van der Velden, (2012) cites the nature of institutional engagement with the student body, maturity, average employment status, national and ethnic background or prior educational experience as having an influence on student engagement. He adds that the interaction between the university and its students depends on what the university views as its role to the students. For example the university's conception of its role in responding to the wider student population or regarding students as part of the university community. It also depends on the way in which it takes decisions, organises itself or responds to change.

The American National Survey of Student Engagement (NSSE 2004; 2005 cited in Hu \& McCormick, 2012) clustered student behaviours, experiences and perceptions into benchmarks of effective educational practice which include academic challenge, active and collaborative learning, student faculty interaction, enriching educational experiences, and supportive campus environment and cite these as crucial benchmarks for student learning and development.

Hu and McCormick (2012) provide the following explanations to the benchmarks. The level of academic challenge refers to the degree of student engagement in studying, especially reading and writing in courses and the perception of institutional emphasis on academic work. Student-faculty interaction is the extent of collaboration between faculty members whether in or outside class. Active and collaborative learning measures the extent to which students engage with other students in class for example making presentations, group projects and questioning. Enriching educational experiences includes engagement with a broad collection of activities such as learning communities, research with faculty, study abroad, service learning and internship. While a supportive campus environment examines the quality of students' relationships with peers, faculty, and administration staff and also perceptions of campus support for students.

However, the theory on student engagement has been criticised for failing to consider the involvement of adult students who do not reside on campus and have other priorities such as work and family which compete for their time and limit their chances of engaging in student activities (Price \& Barker, 2012). Price and Baker (2012) view adult student patterns of learning as focusing on knowledge acquisition which would transform real-life experiences.

\subsection{Study approaches}

Studying is purposeful and therefore requires a deliberate effort on the part of the student to effect it. Different students use different study habits for studying, but literature alludes that only effective study habits help students achieve good results (Sadia, 2005 in Khurshid, Tanveer, \& Qasmi, 2002) hence the need for effective study habits if a student has to study and succeed. Study habits, which some authors call study behaviours/attitudes (Gurung \& McCann, 2011), and others call study skills/strategies (Gettinger \& Seibert, 2002) and yet others call study practices/techniques (Nouhi, Shakoori \& Nakhei, 2008), are "learning tendencies that enable students to work privately" (Ayodele \& Adebiyi, 2013: 72). Khurshid et al, (2002:1) define the same as "buying out a dedicated schedule and an interrupted time to apply one's self to the task of learning." Put simply, they are a student's way or approach of study/learning, "whether systematic, efficient or inefficient" (Ayodele \& Adebiyi, 2013: 72). They are "behaviours functioning to acquire, organize, synthesise, evaluate, remember, and use information" and they include such things as "time management, goal setting, selecting what, how and where to study, taking good notes, reading, and self-testing" (Gurung \& McCann 2011:1). Many factors influence the student's ability to cultivate effective study habits. Ayodele and Adebiyi, (2013) cite health, motivation, anxiety, environment and adequacy of infrastructure as the main factors. A large body of research has established that study habits are a determinant of academic performance since they can positively or negatively influence students' 
competences (Nouhi et al, 2008; Gurung \& McCann 2011; Gettinger \& Seibert, 2002; Khurshid et al, 2002). Conversely, academic competence, which has been established to be associated with application and knowledge of effective study habits, is a fundamental function of study habits. It then goes without saying that good study habits produce positive academic performance, while less of them lead to academic failure.

The body of literature has established four categories of study habits. These are repletion based (such as creating flashcards); cognitive based (e.g. studying with friends, procedural (e.g. time management and meta-cognitive (e.g. testing self-knowledge) (Gurung \& McCann, 2011; Gettinger \& Seibert, 2002). The million dollar question is what exactly are good study habits? Literature is not agreed but tend to concur that 'much depends' with the individual student, and also that good study habits are those that encourage and lead to deep learning (i.e. learning that search for understanding and meaning) rather that to surface learning (i.e. learning that more-or-less mere rote/reproduction learning).

\subsection{Lecturer-student relationship for enhanced learning}

Lecturer-student relationship is not only efficacious but it forms the basis of the social context in which learning occurs (Liberante, 2012). It can be understood to mean interaction between the learner and the instructor which may take the form of an instructor delivering information, encouraging the learner or providing feedback (Sher, 2009: 104). Lecturerstudent relationship may include a learner interacting with the lecturer by asking questions. University students see the right kind of lecturer-student relationship as crucial to their success (Hawk, Cowley, Hill and Sutherland, 2001). Hawk et al (2001) observe lecturer- characteristics that facilitate lecturer-student relationship for enhanced learning. These include: empathy, caring, respect, going an extra mile, passion to motivate, patience and perseverance as well as belief in student's abilities.

A lecturer-student relationship enhances university learning when it gives both the lecturer and the student autonomy. Smith (2014:2) cites Aoki who defines teacher autonomy as the capacity, freedom and/ or responsibility to make choices concerning one's teaching. In the same vein, learner autonomy involves students taking control of their learning. Given that Lecturer-student autonomy facilitates learning, Smith (2014) argues that lecturers particularly teacher-educators need to take aboard pedagogy for teacher-learner autonomy in order to prepare prospective teachers for their own engagement in pedagogy for autonomy with students.

At a university, lecturer-student relationship should be professional if it is to enhance learning. University of Greenwich (2011)'s policy on what it regards to be a professional relationship between lecturers and their students suggests characteristics of a learning-supportive lecturer-student relationship. These are: good communication, clear boundaries, trust and confidence within the lecture-room and laboratory, in one-to-one tutorials and any social gathering that may occur. These features are essential for deprecating incompatible relationships between lecturers and students such as sexual or romantic relationships that potentially compromise university academic standards and student learning.

It must be noted that lecturer-student relationship is lubricated when the former values, respects and meets the needs of the latter. Hallinan (2008) found that a student's attachment to school increases as students' needs are met. Concomitantly, students tend to demonstrate persistence in their studies if they like their teachers (Montalvo, Mansfield and Miller 2007). Teachers who minister to the needs of their students are likeable. Where the lecturer-student relationship is mutual, it becomes more like a play (Giles, 2008) which students enjoy participating though it might be characterised by both scintillating and shocking experiences. Lecturer-student relationship is indispensable to university learning and alongside it there is student-student relationship.

\subsection{Student-student relationship for enhanced learning}

Student-student relationship is critical in enhancing learning. Just as people need people in life, students need other students in their endeavour to learn. Student-student relationship is conceptualised as the exchange of information and ideas that occurs among students about the course in the presence or absence of the instructor (Sher, 2009:104). It can be inferred from the definition that student-student interaction occurs in two scenarios, with or without the lecturer. Sher (2009) further observes that student-student interaction can be experienced through projects and group discussions where students collaborate and share knowledge. The necessity of student-student relationship in university learning implies that lecturers ought to ensure that it prevails.

The question that boggles an educator's mind would be 'how do students relate or interact? Johnson and Johnson (2014) identify three basic ways students interact with each other. They can compete with each other, work individually or work together cooperatively taking responsibility for each other's learning as well as their own. Research studies which 
compare learning in cooperative, competitive and individualistic environments found that students learn more material when they work together cooperatively, talking through the material with each other and making sure that all group members understand than when they compete with each other or work individually (Johnson \& Johnson, 2014; Giles, 2008; Sher, 2009; Bruce, 2007). Research further reveals that students who work together are not only motivated to learn but they have more positive attitudes as well (Johnson and Johnson, 2014). Since cooperative student-student relationship enhances learning, university teaching then should be crafted to facilitate student-student relationships that advance learning. Concomitant researches on university learning confirm the efficacy of student-student relationships to university academic attainment. University of North Carolina (UNC) (2009), Mills (2013) and Eison (2010) found that student-student interaction is enhanced through active learning methodologies like the think-pair-share and buzz groups. It involves students pairing up to think and write about a posed problem. The whole class then discusses the results. Mckeachie and Svinicki (2006) report that buzz groups promote cooperative student-student relationships that enhance learning. They involve the lecturer asking students in a mass lecture to form groups of 5-8 in order to talk about an issue that leads itself to discussion.

Literature is awash with evidence that learning is enhanced when students operate as a community. In essence, research suggests that meaningful learning occurs where a community of learners are socially connected, feel confident about the learning environment and trust other students (Conrad, 2005; Maor, 2003). Sato (2007) who interviewed Japanese university students found that students became more analytic in conversations when they talk to other students particularly in learner-learner dyads. The study recommended that student-student interaction should be promoted in university teaching. Research also tells us that more benefits accrue to students when they share their reasoning with one another (Bruce, 2007; Ramesh, 2012; Brown, 2007). Ontario Mathematics teachers successfully achieved their goals when they urged students to explain and compare their solutions and solution strategies with peers. In this case, studentstudent relationship enhanced Mathematics learning and teaching (Bruce, 2007).

In a technology-mediated environment, research also confirms the pertinence of student-student interaction in enhancing learning. Sher (2009) reports that communication with the lecturers and classmates is needed. It was revealed further that students would like to see more team work and interaction among students. In addition, verbal interaction and conference calls were highly recommended since they enhanced learning (Sher, 2009). The place of student-student relationship in learning cannot be sacrificed. Lecturer should as a prioritise student-student interaction as they teach.

\subsection{Previous studies on students' engagement}

Kuh (2001) cited in Kuh et al (2008: 542) states that student engagement;

\section{... represents both the time and energy students invest in educationally purposeful activities and the effort institutions devote to using effective educational practices.}

The above assertion shows that students should be actively involved in the learning process in and out of classrooms. Such active engagement should be purposefully planned and using worthwhile learning approaches and activities. In a study on student engagement of first year university students, Kuh et al (2008) found that student engagement in educationally purposeful activities is positively related to academic outcomes. This shows that students who invest in time and energy on academic activities have high chances achieving.

In related studies, Mclnnis (2001) found that students were not motivated to study and were unable to manage their own study workload. Inability to manage one's own study workload and failure to stick to a set study time table are all indicators of lack of engagement. Study is a key component of educationally relevant activities necessary for the attainment of learning outcomes. Similarly, Teoh et al (2013) note studies in the United States and Australia showed that students' the level of engagement in higher education was deteriorating. A concern is raised by Kuh (1998) of students who graduate with higher grades yet having done less. It is therefore, important, for students in universities to invest more time and effort in pursuing educationally relevant activities.

In a study conducted in Malaysia, Thang and Azarina (2007) found that the majority of students in public and private universities of Malaysia were not actively engaged in their studies as they relied more on their lecturers in their studies. University students should learn to learn and thereby become independent learners who take control of their own studies. This view is shared by Hofstede, Hofstede, and Minkov (2010:118) who state that '...the purpose of learning is less to know how to do than to know how to learn.'

Coates (2006) argues that students and staff interaction is an important indicator of students' academic engagement at university level. This shows that there is a need for students, while autonomous in their studies, to work 
closely with their lecturers. On way of enhancing this interaction is through students' consultation with lecturers. In this view, student and lecturer interaction will not be limited to the lecture room only. Students with academic challenges may seek assistance by approaching lecturers.

\section{Goal of the Study}

The study sought to establish the extent to which students were involved in academic activities meant to enhance their learning. The researchers engaged in a time-on-task analysis to establish the level of engagement.

\section{Research Methodology}

In the context of this article a research paradigm is taken to mean an approach to research or a set of beliefs and assumptions about research. In short it is equated, in here, to a thought pattern. The guiding thought pattern for this study has been pragmatism because in its evaluation of students' levels of engagement with their studies, this study relied on a combination and shared application of both quantitative and qualitative perspectives in data collection, organization and analysis. The reason for the shared application was to widen the breadth and scope of the study. Mixed Method Approach (Johnson, Onwuegbuzie \& Turner, 2007; Creswell, Klassen, Plano Clark \& Smith, 2011) is therefore an apt way of capturing the study research paradigm. The approach at the same time is constructivist-interpretive (Schwandt, 1994) as the researchers were throughout the research process, outsiders who gauged the students' levels of engagement with their studies from the individual student's perspective. For the researchers, understanding the phenomenon under study involved getting inside the world of those students generating it.

In keeping with the quantitative-qualitative shared application, the study adopted the descriptive research design as it sought to establish students' levels of engagements with their studies through describing what existed as expressed through a description of the students' responses to the given questions. Pretty much as the design sounds, the study described the responses of the students in a systematic and accurate fashion (Jackson, 2009). Notwithstanding the disadvantages of this research design (Gay, 2006), the greatest advantage of this research design was its enabling a wider establishment and evaluation of students' levels engagement with their studies from both numbers and experiences. This enriched the evaluation since it provided both personal elements as well as numerical ones.

The study population consisted of 582 students from five (5) faculties at a selected university in Zimbabwe. The five faculties were: Arts, Social Sciences, Education, Commerce, and Hard Sciences. It was not possible to deal with every single member of the 582 student-population, sampling was therefore necessary. 110 (18, 9\%) students were conveniently or opportunitly selected from the population. The reason for the opportunity sampling was easy of access and inexpensive since the research was not a funded exercise. First the population was put into five subsets/strata according to faculty, and from each stratum 22 students were randomly selected, balancing the numbers where possible by sex. This was meant to ensure that that all the five faculties were represented. Sixty-five male and 45 female students constituted the study sample.

A semi-structured questionnaire was used to gather data for this study. The questionnaire sought to establish respondents' engagement in university academic work. Respondents indicated the time in hours they spent on an academic activity in a week in nine academic activities that were provided. These included preparations for lectures, preparation for assignments, individual preparation for tests, individual preparation for examinations, group discussions with friends, reading in the library, doing computer search for information, reading outside the library and visiting lecturers for consultation. Students were also requested to make any qualitative comments on any issues regarding time spent on the nine academic activities and even add and comment on academic activities that they felt were omitted. This ensured that researchers collected verbatim comments from the respondents.

The researchers enhanced validity and reliability of our study by collecting data across five major faculties at the university so that they could have representative views and avoid bias. Creswell (2012) says that corroborating evidence from different individuals ensure that the study will be accurate because the information draws from multiple sources. The researchers also tried to authenticate our data by having investigator triangulation. The researchers analysed quantitative data statistically with aid of the Statistical Package for Social Sciences (SPSS) version 21. Data were presented through descriptive statistics of frequencies, percentages and means. Qualitative data were analysed through content analysis.

Before the study was carried out, permission to conduct the study was sought and granted by the authorities of the university in which the study was carried out. Informed voluntary consent was sought from the participants. The participants gave written consent to participate in the study and to withdraw if need arose. They were assured of confidentiality and anonymity. 


\section{Results}

Table one shows a time on task analysis of how students spent time on educationally relevant tasks per week.

Table 1: Students engagement in educationally relevant tasks - time on task analysis $(\mathrm{N}=110)$

\begin{tabular}{|c|c|c|c|c|c|c|}
\hline \multirow{3}{*}{ Aspect of Task } & \multicolumn{6}{|c|}{ Time on task per week } \\
\hline & \multicolumn{2}{|c|}{$1-2$ hours } & \multicolumn{2}{|c|}{$3-4$ hours } & \multicolumn{2}{|c|}{5 hours and above } \\
\hline & No. & $\%$ & No. & $\%$ & No. & $\%$ \\
\hline Lecture preparation & 67 & 60.9 & 28 & 25.5 & 15 & 13.6 \\
\hline Assignment preparation & 12 & 10.9 & 33 & 30.0 & 65 & 59.1 \\
\hline Individual test preparation & 25 & 22.7 & 26 & 23.6 & 59 & 53.6 \\
\hline Individual examination preparation & 9 & 8.2 & 25 & 22.7 & 76 & 69.1 \\
\hline Group discussion & 25 & 22.7 & 60 & 54.5 & 25 & 22.7 \\
\hline Library reading & 48 & 43.5 & 41 & 37.3 & 21 & 19.1 \\
\hline Internet searches & 39 & 35.5 & 43 & 39.1 & 28 & 25.5 \\
\hline General private study & 23 & 20.9 & 53 & 48.2 & 34 & 30.9 \\
\hline Consultation with lecturers & 75 & 68.2 & 31 & 28.2 & 4 & 3.6 \\
\hline
\end{tabular}

The time-on-task analysis results show that students' approaches were examination centred as more time was spent on preparation of examinations. It could be gleaned from the statistics on Table 1 that preparation for tests, assignments and examination were push factors for students to allocate more time to such tasks.

Table 2: Time-on-task ranking by Mean

\begin{tabular}{|c|l|c|}
\hline Number & \multicolumn{1}{|c|}{ Task } & Mean \\
\hline 1 & Individual examination preparation & 2.61 \\
\hline 2 & Assignment preparation & 2.48 \\
\hline 3 & Individual test preparation & 2.31 \\
\hline 4 & General private study & 2.11 \\
\hline 5 & Group discussion & 2.00 \\
\hline 6 & Internet searches & 1.90 \\
\hline 7 & Library Reading & 1.75 \\
\hline 8 & Lecture preparation & 1.53 \\
\hline 9 & Consultation with lecturers & 1.35 \\
\hline
\end{tabular}

A look at the ranking of tasks in terms of mean responses further shows that student learning was examination centred as more time was spent on task of immediate importance to obtaining marks. While close interaction between students and lecturers is an important component of students' academic engagement, consultation was ranked as the least of time on task activities. It is also noted that not much time, in comparison to other tasks, was spent on preparation for lecturers.

\subsection{Qualitative comments}

I spend more time reading on my own if I have an examination to write.

I am more serious towards exams.

Assignment preparation consume most of my time because I need to do well in my coursework.

Some lecturers are not on campus when you visit them for consultation.

It is difficult to read in halls of residence because of noise.

I am non-resident and I can do any meaningful study where I stay.

I lose time travelling to and from university since I stay far away from the university.

The above verbatim quotations showed the reasons behind students allocation of time for their academic work.

\section{Discussion}

The study established that preparation for examinations was considered an important task on which much time was allocated by students. This finding confirms what Kirkpatrick and Zang (2011) found in a related study that the main 
purpose of learning for Chinese students was merely to pass examinations. Such students spent most of their time and committed significant effort to pass examinations. Luxia (2007), however, notes with concern the problem of backwash, which is the influence of testing on teaching and learning. The inherent worth of teaching and learning is undervalued if more value is placed on simply passing examinations.

It also emerged from the study that consultation with lecturers was not the least time compared to other academic activities. What could be gleaned from this finding is that students could be viewing themselves as independent learners who would not spend a lot of time consulting or relationships between lecturers and students did not create conducive conditions for students' consultation. The issue of minimal student-lecturer contact through consultations is inconsistent with an assertion by Boateng (2012) that effective student-lecturer interaction can impact positively on quality university education. Inasmuch as students are independent learners, their close cooperation with lecturers outside lecture time is equally important. Boateng (2012) found that in some instances lecturers were too busy to create time for students because of administrative work and assessment activities for large classes.

The study also established that students did not spend as much time on preparation for lectures as they did on other activities. This suggests that students may not have had the culture of reading in preparation of lectures. This finding is also inconsistent with the view by Seery (2010) that it is important for students to engage in pre-lecture activities in order to be adequately prepared for lecturers. This view alludes to the realisation that lecturers should actually make use of pre-lecture activities as a way of encouraging students to prepare for lectures. Time spent working on pre-lecture activities is time well-spent as students will be prepared for content to be handled in lectures.

The study found that internet searches were ranked third from the bottom in terms of activities in which students most of their time per week. This suggests that students were not fully utilising the internet for studies or that internet access was a challenge. Yusuf (2006) notes that internet has revolutionised teaching and learning in universities and students spend considerable amounts of time daily on internet searches as they can access current and relevant literature in all their courses.

\section{Conclusions}

In line with the findings of this study the researchers conclude that time spent on tasks by students was consistent with the examination centred learning and hence preparation of examinations, tests and assignments consumed most of the students' time per week. Tasks that were deemed to be not directly related to passing examinations were not considered important in terms of time allocation.

\section{Recommendations}

The researchers recommend that students in the university should be informed through continuous workshops and other support initiatives of the importance of being actively involved in all the facets of academic life. Learning should not only be focused on passing examinations but on enjoying the inherent worth of learning. Interaction with lecturers through consultation outside lecture hours should be encouraged. Students should also fully utilise internet facilities and spend much time doing literature searches to access current and relevant materials for their studies.

\section{References}

Ayodele, C.S., Adebiyi, D.R. (2013). Study Habits as Influence of Academic Performance of University Undergraduates in Nigeria, Research Journal in Organizational Psychology and Educational Studies 2 (3), 72-75.

Boateng, W. (2012). A Sociological Analysis of Student-Lecturer Interaction in the Wake of Contemporary University Dynamism International Journal of Applied Sociology 2(3): 25-29

Brown, A. (2007). Statistical Cartoons. R-MSOR Connections, 7(4):3-7.

Bruce, D.C. (2007). Student Interaction in the Math Classroom: Stealing ideas or Building Understanding. Ontario: The Literacy and Numeracy Secretariat. www.inspirelearning.ca/english/research/researchRoom.htm Accessed 19 March 2014.

Brusi, R., Portnoy, A., Toro, N. (2013). Student Engagement and Completion in Precalculus Mega Section: Efficiently Assisting Student Engagement and Completion with Communications and Information Technology. Journal of STEM Education, 14(1), 20-25.

Carter, C. P., Reschly, A. L., Lovelace, M. D., Appleton, J. J., Thompson, D. (2012). Measuring Student Engagement Among Elementary Students: Pilot of the Student Engagement Instrument-Elementary Version. School Psychology Quarterly, 27(2), 61-73.

Carter, J. D., Fountaine, T. P. (2012). An Analysis of White Student Engagement at Public HBCUs. Educational Foundations, 49-66.

Christenson, S. L., Stout, K., Pohl, A. (2012). Check \& Connect: A comprehensive student engagement intervention: Implementing with fidelity. Minneapolis, MN: University of Minnesota, Institute on Community Integration. 
Coates, H. (2006). Student engagement in campus-based and online education: university connections. London: Routledge.

Conrad, D. (2005). Building and Maintaining Community in Cohort-based Online Learning. Journal of Distance Education, $20(1): 1-20$. http://www.jofde.ca/index.php/jde/article/viewfile/78/59 Accessed 19 March 2014.

Creswell, J. W. (2012). Educational Research: Planning, Conducting and Evaluating Quantitative and Qualitative Research. Boston: Pearson.

Creswell, J. W., Klassen, A. C., Plano Clark, V.L., Smith, A.C (2011). Best Practices for Mixed Methods research in the health sciences. Retrieved from http://obssr.od.nih.gov/mixed_methods_research/pdf/Best_Practices_for_Mixed_Methods_Research.pdf. Accessed 10 March 2013

Eison, J.E. (2010). Using Active Learning Instructional Strategies to Create Excitement and Enhance learning. Unpublished Manuscript.

Gay, L., Mills, G., A Irasian, P. (2006). Educational research: competencies for analysis and application. New Jersey: Pearson Education, Inc.

Gettinger, M., Seibert, J. K. (2002). Contributions of study skills to Academic Competence, School Psychology Review, 31 (3), $350-365$.

Giles, D.L. (2008). Exploring the teacher-student relationship in teacher education: A hermeneutic phenomenological enquiry. A thesis submitted to Auckland University of Technology. Wellington: Auckland University of Technology.

Gurung, A.R.A., MaCann, C. (2011). How Should Students Study? Tips, Advice and Pitfalls. Retrieved from www.psychlogicalsciences.org/.../how-should-students-study-tips-advice. Accessed 10 March 2014

Hallinan, M.T. (2008). Teacher Influences on Students' Attachment to School. Sociology of Education, 81(3): 271-283. From http://dx.doi.org/10.1177/003804070808100303 Accessed 17 March 2014.

Hawk, K., Cowley TE, Hill j, Sutherland S 2001. The Importance of Teacher-Student Relationship for Maori and Pasifika Students. www.educationcounts.gvt.nz/publications/tertiary_education/.../10 Accessed 20 March 2014.

Hofstede, G., Hofstede, G. J., Minkov, M. (2010). Cultures and organizations: Software of the mind (3rd ed.). New York, NY: McGrawHill.

Hoppe, Jackson, S.L. (2009) Research Methods \& Statistics: A Critical Thinking Approach. Belmont, CA: Wadsworth.

Hu, S., McComick, A. C. (2012). An Engagement Based Student Typology and its Relationship to College outcomes. Springer, 53, 738754.

Jackson, S.L. (2009) Research Methods \& Statistics: A Critical Thinking Approach. Belmont, CA: Wadsworth.

Johnson, T.R., Johnson, W.D. (2014). Encouraging student-student interaction. National Association for Research in Science Teaching (NARST). https://www.narst.org/publications/researchencourage2.cfm Accessed 18 March 2014.

Johnson, R.B, Onwuegbuzie, A.J., Turner, L.A. (2007). Toward a definition of mixed methods research. Journal of Mixed Methods Research, 1, 112-113.

Khurshid, F.,Tanveer, A., Qasmi, F. (2002). Relationship between Study Habits and Academic Achievement among Hostel Living and Day Scholars' University Student, British Journal of Humanities and Social Sciences, 3(2), 34-42.

Kirkpatrick, R., Zang, Y. (2011). The negative influences of exam-oriented education on Chinese high school students: backwash from classroom to child. Language Testing in Asia 1 (3): 36 - 45

Kuh, G.D., Cruce, T.M., Shoup, R., Kinzie, J. (2008). Unmasking the Effects of Student Engagement on First-Year College Grades and Persistence. The Journal of Higher Education, 79 (5): 540-563

Kuh, G. D. (1998). How are we doing? Tracking the quality of undergraduate experience from the 1960s to the present. Review of higher education, 21 (2): 90-120.

Landis, R. N., Reschly, A. L. (2013). Re-examining Gifted Underachievement and Dropout through the lens of Student Engagement. Journal of the Education of the Gifted, 36(2), 220-249.

Liberante, L. (2012). The importance of teacher-student relationships as explored through the lens of the NSW Quality Teaching Model. Journal of Student Engagement: Education Matters, 2(1): 2-9.

Lysne, S. J., Miller, B. G., Eitel, K. B. (2013). Exploring Student Engagement in an Introductory Biology Course. Journal of College Science Teaching, 43(2), 14-19.

Maor, D. (2003).Teachers' and Students' Perspectives on Online Learning in a Social Constructivist Learning Environment. Technology, Pedagogy and Education, 12(2): 201-218.

McInnis, C. (2001) Signs of Disengagement? The changing undergraduate experience in Australian universities. Inaugural Professorial Lecture. Centre for the Study of Higher Education, The University of Melbourne.

Mckeachie, W.J., Svinicki, M. (2006). Mckeachie's Teaching Tips: Strategies, research and theory for College and University Teachers. Boston, M.A: Houghton Mifflin.

Millis, B.J. (2013). Idea paper 53: Active Learning Strategies in Face-to-Face Courses. Manhattan: The idea Centre. From www.theideacentre.org Accessed 15 December 2013.

Montalvo, G.P., Mansfield, E.A., Miller, R.B. (2007). Liking or disliking the teacher: student motivation, engagement and achievement. Evaluation and Research in Education, 20(3): 144-158. From http://dx.doi.org/10.2167/eri406.0 Accessed 19 March 2014.

Ndudzo, D (2013). An Evaluation of Student Engagement in the ODL Higher Education Context in Zimbabwe Journal of Business and Management 15 (2): 57-64

Nouhi, E., Shakoori,A., Nakhei, N. (2008). Study habits, skills, and academic achievement of students in Kerman University of medical sciences, Journal of Medicine Education, 12 (3), 77-80.

Price, K., Baker, S. N. (2012). College Campuses: Is the NSSE an Appropriate Measure of Adult Students' Engagement? The Journal of Continuing Higher Education, 60, 20-32. 
Ramesh, N.I. (2012). Enhancing the student learning experience through greater engagement and interaction in Mathematics and Statistics. http://www.cms.gre.ac.uk/staff/details.asp?id=258 Accessed 18 March 2014.

Sato, M. (2007). Social Relationships in Conversational Interaction: Comparison of Learner-learner and Learner-NS Dyads. Japan Association for English Teaching (JALT) Journal, 29(2):183-208.

Schwandt, T.A. (1994) Constructivist, interpretivist approaches to human inquiry. N.K.Denzing \& Y, S. Lincoln (eds), Handbook of qualitative research, (p 118-137). Thousand Oaks, C.A: Sage

Seery, M.K (2010). Using Pre-Lecture Resources in your Teaching: A Short Guide. http://www.dit.ie/lttc/media/ditlttcl documents/ttcresources/Using\%20Pre-Lecture\%20Resources\%20in\%20your\%20teaching.pdf. Accessed 4 April 2013

Sher, A. (2009). Assessing the relationship of student-instructor and student-student interaction to student learning and satisfaction in web-based online learning. Journal of Interactive Online Learning, 8(2): 102-120. From www.ncolr.org/jiol Accessed 18 March 2014.

Smith, R.C. (2014). Teacher education for teacher-learner autonomy. Centre for English Language Teacher Education (CELTE) University of Warwick. www.warwick.ac.uk /-elsdr/teacher_autonomy.pdf Accessed 19 March 2014.

Teoh, H.C., Abdullah, M.C., Roslan, S., Daud, S (2013). An Investigation of Student Engagement in a Malaysian Public University. Procedia - Social and Behavioral Sciences 90: 142 - 151

Thang, S.M., Azarina, A. (2007). Investigating readiness for autonomy: A comparison of Malaysian ESL undergraduates of three public universities. Reflections on English Language Teaching, 6(1), 1-18.

University of Greenwich (2011). Professional Relationships Between Staff and Their Students-Policy London: University of Greenwich. www.gre.ac.uk/.../relationship-Between-Staff-and- their-students-gu Accessed 19 March 2014.

University of North Carolina (2009). Classroom Activities for Active Learning. From http://cfe.unc.edu Accessed 24 December 2013.

Van der Velden, G. (2012). Institutional Level Student Engagement and Organisational Cultures. Higher Education Quarterly, 66(3), 227247.

Yusuf, M.O. (2006). Using the Internet for Teaching, Learning and Research in Higher Education Journal of Nigerian Association of Teachers of Technology, 6 (1), 163 - 171, 